УДК 159.923.000.28

doi: 10.15330/ps.9.1.21-29

\author{
Ольга Климищин \\ Прикарпатський національний університет \\ імені Василя Стефаника \\ klymyshyn@meta.ua

\section{ФЕНОМЕНОЛОГІЯ СУБ'ЄКТНОСТІ ЛЮДИНИ З ПОЗИЦІї ХРИСТИЯНСЬКОї ПСИХОЛОГІї}

\begin{abstract}
У статті представлено християнсько-орієнтовану парадигму суб'єктності людини. Історичний поступ психологічної науки закономірно приводить до телеологічно детермінованого холістичного представлення людини як иілісної тілесно-душевно-духовної реальності, носія і суб'єкта духовних прагнень $і$ здатностей. Таке бачення притаманне інноваційному для сучасної вітчизняної психології напрямку - християнсько-орієнтованому, заснованому на експозиції християнської персонології на постнекласичний тип рачіональності.Суб'єктність $\epsilon$ складним багаторівневим феноменом, функціональний зміст якого визначає онтологічна доцільність існування людини як триєдності тіла-душі-духа. У трансцендентально-онтологічній природі людини, їі сакраментальності наявний не лише ціннісний прообраз - «Взірецьь» ї̈ розвитку, щзо телеологічно його спонукає, але й міститься необхідна конфігурація задатків, які забезпечують реальну спроможність суб'єкта до духовного самоздійснення (реалізація каузальної причинності). Суб'єктність репрезентує божественне і людське в їх синергійному союзі щуодо ініціації, актуалізації та реалізації життєвої активності на трьох рівнях: духа - реалізачія свободи вибору, ціннісне самовизначення і цілепокладання; душі - знаходження особистісних сенсів шляхом переживання; рівень тіла - реалізачія поведінкових програм у конкретних видах предметної діяльності. Водночас душевна іпостась визначає як пріоритетний інтуїтивний спосіб актуалізації суб'єктності, а духовна задає спосіб ї̈ реалізації через вчинок. Божественний Дух визначає творчий характер життєвої активності людини як Любов (з Любові, у Любові, для Любові), надаючи людині онтологічного статусу співтвория. Любов як смислова диспозиція мотивованої духом особистості виступає провідним чинником Богонатхненної вчинкової активності.
\end{abstract}

Ключові слова: особистість, суб'єктність, духовний розвиток, духовна активність, психічна активність, соціальна активність, культуро- і життєтворчість, біо-фізіологічне функиіонування, тілесна експресія.

Постановка проблеми. В трансцедентально-онтологічній природі духовності людини (iі сакраментальності) поміщено не тільки прообраз - «Взірець» їі розвитку, що телеологічно його спонукає, але й міститься «пряма вказівка» на реальну спроможність суб'єкта до самоздійснення духовним вектором (реалізація каузальної причинності). Духовна іпостась визначає функціональний статус людини як співтворця, як духовного суб'єкта. Ноологічна сутність людини зумовлює іiі доцільну творчо-вольову спрямованість та визначає здатність до вибору добра i заперечення зла на основі самопізнання та самовизначення у спосіб альтруїстичного служіння, гедоністичного самообмеження, самопожертви аж до самозречення тощо.

Парадигма суб'єктності людини в останні десятиліття знайшла певне визнання у наукових дослідженнях багатьох відомих вчених (К. О. Абульханова, А. В. Брушлинський, Е. I. Ісаєв, Н. Ф. Каліна, З. С. Карпенко, І. В. Кузьменко, С. Л. Рубінштейн, В. І. Слободчиков, В. О. Татенко, Т. М. Титаренко та ін.), наукові розробки яких підтвердили ії евристичну цінність та функціональну придатність. «Необхідність запровадження суб'єктного підходу в науках про людину, й зокрема у психології, пояснюється тим, що суто людське, душевне, духовне, психічне не може визначатися як “ззовні" детерміноване без урахування його відношення як цілого до самого себе і до інших цілих... Сучасна психологія активно експлуатує категорію суб'єкта при дослідженні проблем людської самості, феномена “Я”, намагається подолати розірваність людського існування на суб'єктний і об'єктний плани шляхом онтологізації суб'єктності, індивідуалізації форм, змістів і смислів суб'єктної активності людини»[8, с. 325].

Зокрема, 3. С. Карпенко розглядає суб'єктність як «саморушну причину сущого, універсальний принцип переходу можливих станів суб’єкта в дійсність інтенціональних предметностей. Суб'єктність людини - це формовияв іiі інтенціонального воління 3 використанням психофізіологічних ресурсів організму й можливостей соціокультурних 
контекстів» [2, с. 159]. I. В. Кузьменко трактує суб'єктність як «властивість психіки людини, яка виражається у самодетермінованому, свідомому вияві зовнішньої та внутрішньої активності на трьох рівнях: «індивід», «особистість», «індивідуальність» [3, с. 97]. На думку В. О. Татенка, поняття «суб'єктність» містить у собі наукове знання про сутнісний онтопсихологічний проект автентичного людського буття, а з іншого - фіксує такі сутнісні ознаки людської активності, як автономність, самодостатність, цілісність і гармонійність, зорієнтовує на пошук внутрішніх джерел та рушійних сил розвитку людської істоти, підкреслює іiі авторське право, спроможність починати причинний ряд із самої себе, а тому нести персональну відповідальність за вдіяне і скоєне» $[8$, с. 349].

«У психології, що не обмежує свій предметний інтерес поняттям рефлексу, спроба віднаходження психологічних критеріїв суб'єктності може викликати образ “духа” як носія інтенцій і потенцій вільного світопізнання і самопізнання через (i задля) світотворення i самотворення, а також уявлення про “душу” як інстанцію, що дозволяє духові автентично самоактуалізовуватися в кожному конкретному людському індивіді» [8, с. 333].

Мета статті: обгрунтування змісту християнсько-психологічного підходу до феномену суб’єктності як автентичної властивості духовної природи людини.

Виклад основного матеріалу. Виходячи 3 християнсько-психологічного розуміння людини як комплементарної єдності тіла-душі-духа, суб'єктність розглядається як властивість та принцип функціонування духовної природи людини. «Суб'єктність - це Дух, що організує природну динаміку душі індивіда, це те, що вимагає від неї постійного руху і важкої духовної роботи... Людина вже багато століть при народженні "нагороджується" часткою цієї реальності, живе “під іiї патронатом", але ще й досі на раціональному рівні не приймає своєї потрійної сутності» [1, с. 137, 138].

У контексті досліджень фрактальної психології, О. А. Донченко висловлює припущення, що психофрактали - це фізична реальність, яка стоїть за поняттям «душа». Сутність людини становлять, на iї думку, космопсихічні (Бог-Отець), біопсихічні (Бог-Син), психосоціальні (БогДух Святий) сили. «Мовою психології Бог-Отець і Бог-Син - це психофрактал індивіда, а БогДух Святий - це і є суб’єктність» [1, с. 137].

Активність, дієвість - ознака, принцип існування в людській плоті і душі духа. Цей постулат суголосний $з$ припущенням В. О. Татенка про те, «що лінійно-нелінійний процес порівневої (біопсихічний та соціопсихічний рівні) ініціативної самоактуалізації суб'єктності за власне людським проектом розпочинається вже зі стадії зиготи. Зрозуміло, що цей процес може відбуватися лише за певних умов (фізичних, хімічних, біологічних, психологічних, соціальних тощо), які є необхідними, але недостатніми для розвитку суто людського в людині. Якраз “достатності” такому розвитку надає притаманна кожному здоровому індивідові внутрішня інтенція і потенція його становлення людиною, а також відповідна ініціативна активність само творення» [8, с. 328].

Спробуймо розширити зміст цього припущення. Момент зачаття, як і подальший розвиток людини, з християнсько-психологічної точки зору, відбувається 3 волі Творця посередництвом Духа. Таким чином, «щойно утворена» (як і сама можливість ії утворення) зигота $\epsilon$ свідченням присутності у ній творчого начала життя - Духа. В попередньому розділі, розкриваючи зміст одного з факторів розвитку релігійної віри - усвідомлення складності і досконалості людини і Всесвіту, - ми заторкували проблему доцільної організації людського організму та можливостей “сліпо-глухо-німої” природи забезпечити процес диференціації клітин згідно з програмою “розгортання" ДНК”. У цьому контексті зазначмо, що уже на біопсихічному рівні людина є суб’єктом, активність якої як здатність до саморозвитку невід'ємна властивість її духовної природи.

Суб'єктність репрезентує божественне і людське у їх дуалізмі-союзі щодо ініціації, актуалізації та реалізації життєвої активності, насамперед, вчинків. Божественне, представлене в іпостасі духа, визначає апріорний якісний зміст цієї активності як Любов (з Любові, у Любові, 
для Любові) та визначає (встановлює) відповідний функціональний принцип здійснення активності - творення, надаючи людині онтологічного статусу співтворця. Любов як смислова диспозиція мотивованої духом особистості виступає провідним чинником Бого-натхненної вчинкової активності.

Емпіричне людське буття репрезентується рівнями душа-тіло. Зокрема, що стосується душевного світу, то він представлений доцільною індивідуальною конфігурацією апріорних потенцій та реальних акциденцій суб'єктної активності. Мовою ХХІ століття, рівень душі - це рівень «програмного забезпечення суб'єктності». На цьому рівні актуалізуються інтенційні та потенційні засади активності, відбувається їх взаємна трансформація та реалізація. Назагал вони $\epsilon$ своєрідною «динамічною матрицею суб'єктності», в якій постійно відбуваються структурні зміни і водночас зберігається унікальний патерн організації” [1, с. 124].

«Організаційна закритість - це мета, Божий задум, призначення. Проте через неї як через відкриту структуру постійно іде інформаційно-енергетичний потік, який вона переробляє і до якої ій необхідно адаптуватися, а може - інтегруватися, а може актуалізуватися. Цей рухливий процес об'єднує патерн і структуру в єдине, від чого залежить доля структури» [1, с. 118-119]. Організаційна закритість є умовою збереження «індивідуального ресурсу» потенційної спроможності суб'єктної активності. Інтегративна єдність якісного змісту активності (духовного божественного) та функціональної здатності (суб'єктного людського) визначає суть духовно-душевної активності людини (рис. 1).

Інформаційно-енергетичні потоки, які «живлять» «матрицю суб’єктності», надходять 3 двох інформаційно-енергетичних джерел - трансцендентного та іманентного. У свою чергу, трансцендентне джерело постає у трьох різновидах: отнологічно-трансцедентному (Творець $\rightarrow$ людина), феноменологічно-екзистенційному (людина $\rightarrow$ Світ, в якому людина існує) та трансцендентально-іманентному (аспект самопізнання та самоставлення). Вони $\epsilon$ співвідносними з рівнями функціонування людини як суб'єкта: онтологічно-трансцендентне метасуб'єктний рівень, феноменологічно-екзистенційне - інтерсуб'єктний та іманентнотрансцендентальне - інтрасуб'єктний, що сукупно уособлюють системну детермінацію духа $\rightarrow$ душі $\rightarrow$ тіла. 


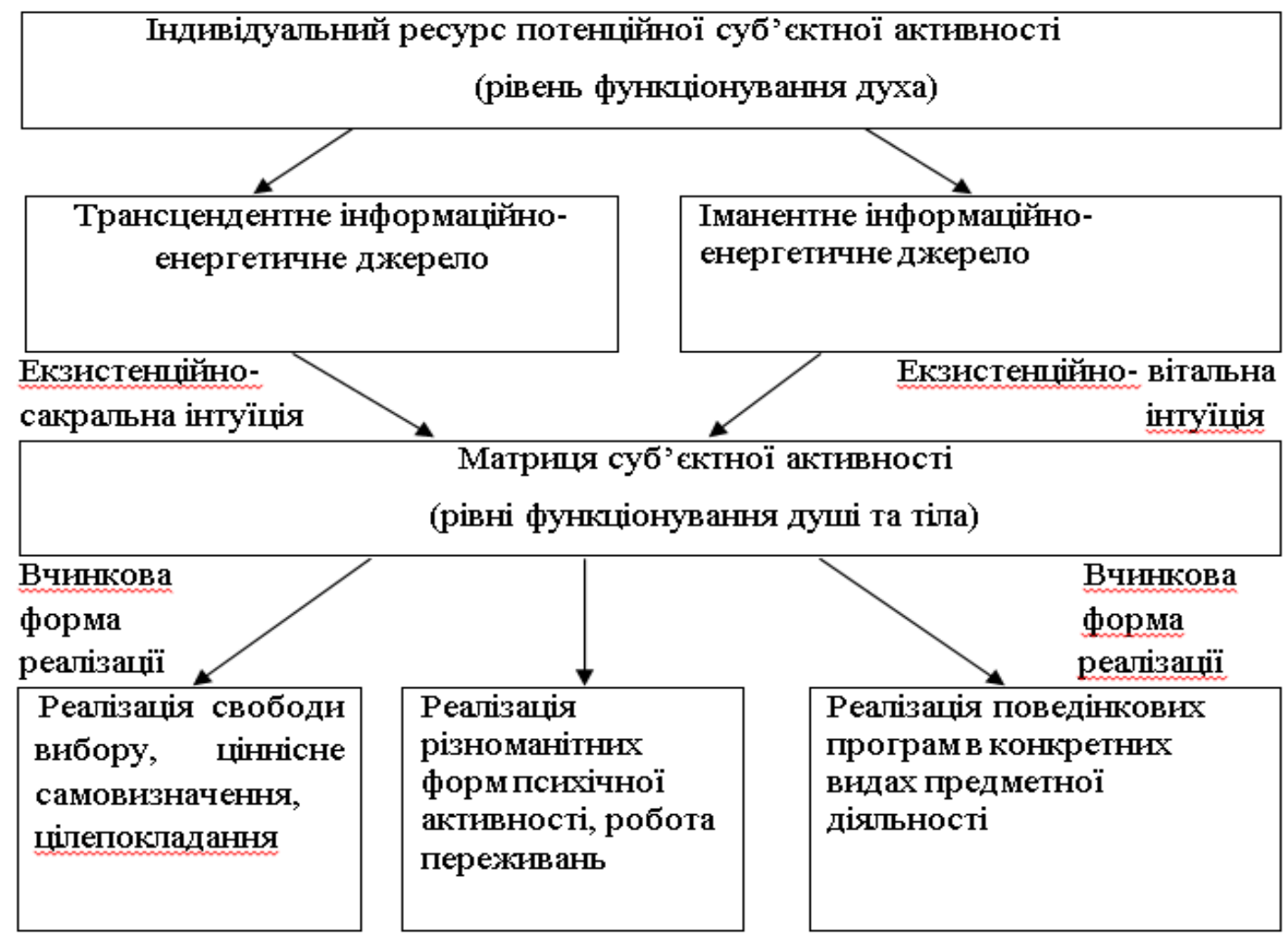

Рис. 1. Феноменологія реалізації суб’єктності як автентичної властивості духовної природи людини

Інформаційно-енергетичний потік онтологічно-трансцедентного джерела має виключно духовну орієнтацію. Його метафізичною метою, Божим задумом щодо людини є ініціація та допомога в реалізації потенційних можливостей людини розвиватися за Його планом. Інформаційно-енергетичний потік феноменологічно-екзистенційного джерела забезпечує соціокультурну мотивацію і творче самовираження особистості. Іманентно-трансцендентальне джерело інформаційно-енергетичного потоку підтримує наявний стан самоконституювання суб’єкта та «живить» «зону його найближчих перетворень». Зупинімося детальніше на цьому останньому.

Так, одним із ключових механізмів актуалізації інформаційно-енергетичним потоком іманентного джерела є інтуїція. Остання у розширеному розумінні трактується як духовнопізнавальна здатність людини до осягнення сенсу потенційних можливостей та реальних вчинків людини як тілесно-душевно-духовної істоти (iї божественної та людської природи). «Ноосферні процеси безпосередньо нами переживаються, спостерігаються та усвідомлюються. Через них і в них наш дух виступає як творчо-вольова і творчо-діяльна сила. Водночас зауважимо, що сутність нашого духа ніколи не вичерпується психологічною і ноологічною актуалізацією, яка складає лише певну фазу нашого життя-пізнання» [5, с. 193-194].

У цьому контексті фундаментальне з'ясування ситуації одухотворення (в 3. С. Карпенко - менталізація) пропонує В. О. Татенко в концепті субстанцііальних інтуїиій суб'єктного ядра «сутніснного коду» онтогенетичних самоперетворень індивіда в напрямку досягнення ним справді людського буття у світі. Вчений виокремлює: екзистенціальну - «я присутній, існую, живу...»; інтенціальну - «я хочу, бажаю, прагну...»; потенціальну - «я можу, вмію, здатен...»; віртуальну - «я обираю, маю намір, вирішую...»; актуальну - «я реалізую, виконую, досягаю...»; рефлексивну - «я оцінюю, примірюю, порівнюю...» експірієнтальну - «я маю, вміщую, володію...» інтуїції [7, с. 49]. На наш погляд, екзистенціальна інтуїція постає у двох змістовно-відмінних, але взаємодоповнюючих формах: як екзистенційно-вітальна та 
екзистенційно-сакральна (трансцедентна). Перша стосується тільки людської природи духовності і передбачає виникнення переживань і почувань людини на рівні іiі душі. Друга стосується переживань людини як особистості, індивідуальності, але не як «просто існуючої», а у прямому відношенні до Творця. Екзистенційно-сакральна інтуїція передбачає відчуття людини своєї сакральності, своєї духовної самості у Бозі.

«Божа Реальність залишається для нас потаємною і не пригнічує людину своєю необхідною очевидністю. Цим недосконалий людський дух приховується від безвимірного, від безмежного, всемогутнього Буття Божого, від того, що перевищує іiї (людини) сили - iї розум, уяву, інтуїцію, волю тощо. Це також зберігає нашу свободу перед Богом. Осягнення божественної реальності, Буття Божого здійснюється поступово, інтуїтивно, в строгій божественній відповідності із готовністю людини до містичної зустрічі з Богом, до якої веде нас віра і містична інтуїція. Бог не осягається елементарним, раціональним людським сприйняттям. Крок за кроком Він входить у свідомість і душу людську через природу, через нашу драматичну історію, через віру і любов, через інтуїтивне відчуття таїни і переживання священного. I врешті-решт через Одкровення Сина Божого і Сина Людського - Ісуса Христа. 3 цими психологічними і ноологічними феноменами пов'язане і історичне розмаїття релігійного досвіду людства, які виражають різні фази та рівні людського богопізнання. На цьому грунті ми маємо певне право говорити про деяку спорідненість всіх великих релігій світу, яка пов'язана 3 єдністю людської природи, єдністю та однорідністю нашого земного буття, а також зі схожими переживаннями, які викликає у нас, людей, наша духовна інтуїція, наше відчуття Небесного, Надприродного, Божественного і думки про ці надприродні реалії. Справжнім осереддям цього відчуття Богоприсутності у світі $є$ почуття і містична інтуїція благоговіння, яке споріднює між собою того чи іншого адепта великих світових релігій. Навіть атеїст в якісь моменти свого життя виявляється причетним до цього відчуття і може переживати (інтуїтивно!) близькість “невідомого Бога". Як час, простір, ефір пронизують всі тіла і предмети світу, всієї Світобудови, так і згідно з нашим внутрішнім, глибинно інтуїтивним відчуттям божественної сутності добра, краси, сили, значущості життя, справедливості пронизують все добре, прекрасне, святе, могутнє, значне і справедливе у нашому житті» [5, с. 172-173].

Теорія розвитку людини як суб'єкта власного життя в рамках християнської психології набуває очевидного християнсько-орієнтованого змісту. Дотримуючись логіки побудови такої теорії за іiі основними категоріями, означеними В. І. Слободчиковим, - об'єкт (що розвивається?), його механізми чи рушійні сили (як дещо розвивається?), вектор розвитку (куди дещо розвивається?), результати розвитку (у що дещо розвивається?), означується такий теоретичний проект. Людина як комплементарна єдність тіла-душі-духа становить об'єкт розвитку, основними рушійними силами якого є онтологічні потенційні даності та інтенційні умови, онтологічне духовне устремління (повторимось «від звіра до Бога2) є метою статись активним учасником реалізації Божого плану спасіння.

3 богословської точки зору, первинною онтологічно зумовленою активністю людини $є$ вільний вибір. Людина, створена за образом і подобою Божою, від початку була наділена свободою вибору. Про це останнє вже йшлося раніше, тож тут уточнимо те, що видається важливим у контексті обговорюваної проблематики. Насправді вільним у своєму виборі $\epsilon$ тільки той, хто дозрів у своїй структуральній свободі, тобто здатний підпорядкувати духові свою душу і тіло. Тільки в цьому випадку можна наблизитись до свободи Бога, і тільки за цих умов можна бути вільним у виборі - сповняти добро. Марк Аскет уточнив, що «добровільний вибір» полягає не просто у свободі вибору, а в свободі любити, тому що він $є$ вибором з любові. Благодать вільного вибору полягає в тому, щоб «не звертатися до зла, а залишатися в добрі». Відповідно, дотримання заповідей віруючою людиною - це не $\epsilon$ щось для неї примусове, але в дусі християнської любові є її активною життєвою позицією любові (“Якщо любите ви мене, то мої заповіді берегтимете”»/Ів. 14:15/). 
У чисто психологічному сенсі «свобода людини як суб'єкта полягає в тому, щоб стати особистістю і припинити жити у відповідності із зовнішніми принципами, щоб здійснювати трансцеденцію, виходячи таким чином за межі себе, щоб вибирати себе, бути самим собою й нести відповідальність за свій вибір перед самим собою. «Людина, що втрачає здатність регулювати свою активність із середини, стає все більш беззахисним об'єктом маніпуляції і навіть суб'єктивно починає тяжіти до статусу підлеглої, підпорядкованої волі іншого, який уособлює силу і владу» [6, с. 442].

Повертаючись до християнсько-психологічного ракурсу осмислення суб'єктності через категорію вибору, означмо ще одну позицію. Динаміка суб'єктності - це сходження людини від «людини старої» до «людини нової». Сутність «старої» людини визначає їі Его-центрованість, а моральною характеристикою іiі «хотіння» $\epsilon$ маніпуляція, підпорядкування, користолюбство. «Нова» ж людина в основу свого буття ставить Бога. Джерелом ії прагнень $\epsilon$ не вона сама, а Бог. Відмінність цих орієнтацій не змістово-ідейна, а функціональна. I перша, і друга вірить у Бога, але тільки «нова» людина робить його «принципом» свого буття, активно-діяльним центром, з яким вона «узгоджується» у вільний та унікально властивий ій індивідуальний спосіб. Довершеним прототипом “нової” людини, наприклад, можна вважати матір Терезу, Отця Піо.

«Нова людина» - це істинна людина. У свою чергу, В. І. Слободчиков вбачає в істинній людині святу людину (відомий психолог А. Маслоу сказав якось, що суспільство святих людей - це і є справжнє людство), процес становлення якої охоплює весь їі склад - дух, душу і тіло і $\epsilon$ обожненням (теосис), відновленням і набуттям образу і подоби Божої. «Цілісний дух людини, проявляючись через свою ноосферу раціональності, етичності та естетичності в безмежній множині думок, почуттів і бажань, разом з тим завжди залишається самим собою, зберігаючи свій якісний зміст і свою богоподібну сутність» [5].

Зазначмо, що позиція нової людини є активною, співдіяльною. Дехто може сказати, що це парадокс свободи, мовляв, якщо людина чинить волю Творця, то вона перестає бути вільною. Та це не так. Сама природа Бога має ексцентричний характер - Бог нічого не хоче для себе, принципом Його буття є «Буття від Себе». Таким чином, виконуючи волю Творця, людина проявляє власну волю в усій повноті ії «видимої» і «невидимої», «пізнаної і непізнаної» реальності власного буття («Благословенний ти, Господи Боже, Вседержителю, що знаєш думки людські, що відаєш те, чого ми потребуємо, і багато більше, ніж ми просимо, або розуміємо.., і провидінням твоїм дай нам усе корисне...» [4, с. 175]).

Символічним образом життєвої позиції «нової» людини є людина 3 піднятими вгору та широко розпростертими руками, відкритими долонями, як символ потреби сходження Божої благодаті, готовності прийняти Божу волю, спроможності реалізувати їх у своєму житті, але не для себе, а задля ближніх, вона особистість-співтворець з відповідною місією. Очевидно, суть останньої «у тому, щоб ствердитись у статусі мудрого творця, свідомо й відповідально розв'язувати гносеологічні та онтологічні суперечності біологічного й соціального, психічного й непсихічного, індивідуального й суспільного, неповторного й універсального, суб'єктивного й об' єктивного, а також істинного й неістинного, доброго й злого, прекрасного і потворного, сутності й існування, життя і смерті, буття й небуття» [6, с. 519].

Суб'єктність «нової» людини стає спроможністю до духовного розвитку з очевидною пріоритетністю ii онтологічно-трансцендентого полюсу, 3 превалюванням трансцендентноекзистенційної інтуїції. А твердження християнсько-орієнтованого змісту «Вже живу не я, а живе в мені Христос» стає внутрішньою реальністю, реальністю, яка, проектуючись назовні (рівень інтерсуб'єктості), стає видимою ознакою духовно-душевних перетворень людини.

На нашу думку, суб'єктність - як і особистісність, індивідуальність - $є$ онтологічними ознаками людини, оскільки у них спільне джерело походження, спільна природа - ноологічна сутність. Водночас суб'єктність у стосунку до особистісності та індивідуальності, стає можливістю, умовою, засобом, інструментом розвитку останніх. Як даність та властивість духа, 
суб'єктність може бути не досить зреалізованою, певною мірою не вповні актуалізованою, а також здеформованою (зміст та наслідки визначаються ступенем деформації останньої). Послуговуючись запропонованими 3. С. Карпенко категоріями «картографії інтегральної суб'єктності», підкреслимо, що з християнсько-психологічної точки зору людина потенційно $\epsilon$ абсолютним суб'єктом - це свого роду початок i кінець іiі духовного розвитку, а іiі полісуб'єктність є морально-екзистенційним центром ії духовного становлення, оскільки міра розвитку духовності людини визначається мірою доброчинної участі людини в житті Іншого, ближнього.

Не заперечуючи важливість соціально-психологічних чинників в розгортанні суб’єктності людини, все ж акцент робимо на самій людині, іiі духовній організації як визначальному факторі активізації суб'єктності. В християнсько-психологічному розумінні онтологічна свобода людини є передумовою самовільної реалізації потенційної суб'єктності у відповідний індивідуальний спосіб. 3 християнсько-психологічної точки зору субстанційний зміст суб'єктності людини співпадає з потенційним, не завжди очевидним психо-біологічним субстратом, тобто людина має у собі все необхідне для того, щоб стати тим, ким вона може стати залежно від низки здійснених життєвих виборів.

Очевидно, не може бути мови про загальноприйнятий спосіб стимулювання суб'єктності людини в умовах іiї виховання чи навчання. Має слушність В. О. Татенко, коли стверджує, «що неправильно говорити про якесь цілеспрямоване формування індивіда як суб'єкта психічної активності, але тільки про більш чи менш сприятливі соціо-біологічні умови, які сприяють його спонтанному саморозгортанню, саморозвитку, самоздійсненню... Таким чином, мова повинна йти не про виникнення суб'єктної активності в дошкільному, молодшому шкільному, підлітковому або якому-небудь іншому віці, але про іiі генетичні рівні і форми. Причому на кожному з етапів онтогенезу індивід виступає як цілісний суб' єкт психічної активності певного рівня розвитку (спочатку несвідомого, а потім все більше свідомого)... Суб'єкт завжди є (має себе), “наявним” і завжди перебуває в стані самостановлення, самовдосконалення i саморозвитку» [7, с. 54].

Саме духовна іпостась визначає суб'єктний принцип реалізації людської активності як творчого самотрансцендування у формі вчинку. Вчинок $є$ вищою формою душевно-духовної активності (В. А. Роменець), показником рівня розвитку (від автора. - стану) душі людини (О. А. Донченко) та міри використання координувальної здатності їі духа по відношенню до душі та тіла. «Божественне життя не накладається на нас, як одежа на тіло; воно всередині в нас; воно просочує нас, як сік дерево з усіма його частинами. Воно проникає в усе наше єство, як душа в тіло, так, що відтепер кожен наш вчинок вже не просто людський, а богочоловічий, який тим самим набуває неминуче вічної вартості» [4, с. 177].

«Емпірична людина, конкретний індивід, якому відкрилась таємниця його існування як конечного буття, обмеженого часовим відрізком між народженням і смертю, приречений стверджувати себе у протилежності як жива нескінченність, як вічне перебування, а отже, не просто проживати відведений час, не просто існувати, а творити своє життя як історію вчинків, як історію сутнісного існування. Чим меншу відстань між окремими вчинками вдається людині встановити, тим більше історія іï життя наближається до життя як вчинку, до трансцендентального існування, а отже, до єднання 3 вічним, божественно-космічним» [6, c. 519-520].

Життя людини ознаменоване вчинком від моменту ії зачаття, хоча й опосередковано через інших. Ствердне «так» іï батьків на факт іï «зародження» $є$ їх первинною «вчинковою формою зустрічі», в якій відтворено ставлення до неї ще ненародженої. «Для екзистенціалізму, що в своїх коріннях органічно переплетений з феноменологією, світ, у який “закинута людина і якому при першій зустрічі вона каже “так”, - це світ панування необхідності, детермінації іззовні, пригнічення неповторно-індивідуального, особистого загальним, заперечення свободи, це світ, в якому знищується оригінальність особистості» (М. О. Бердяєв) [6, с. 513]. 
3 богословської точки зору, онтологічний смисл людського життя полягає в активній участі людини в реалізації Божого плану. Її активна позиція $\epsilon$ відповіддю на онтологічний заклик, який здатна почути тільки вона - людина, що робить і1і, з одного боку, спроможною до вчинків, а з іншого - наділяє іiі відповідальністю за них. Враховуючи еклезіологічну точку зору богослов'я, можна сказати, що Бог-Отець ініціює вчинкову духовну активність людини, БогСин iї інституює, а Бог-Святий Дух конституює. Іпостась Бога як Сина визначає христоформність відповіді людини на онтологічний заклик. Вельми вдале символічне порівняння співдії Бога, Сина та Святого Духа знаходимо в Отця Церкви К. Срусалимського Бог є джерелом річки, Син - іiі руслом, а Святий Дух - власне водою [4]. В такому розумінні вчинок людини за своєю формою $є$ завжди христоцентричним, а його духовний зміст $\epsilon$ відображенням рівня індивідуальної спроможності людини до реалізації своєї істинної природи.

«Завжди залишаються засади неосяжності, непередбаченості поведінки і життя людини, що зумовлене належністю людської істоти до вищого, надприродного начала, її причетності до Животворної Божої Сили, яка створює і дарує справжню реальність безумовно значущого буття. У свободі людини здійснюється іiі належність до істинного божественного буття. Тут реалізується іiі боголюдяність (христоцентричний аспект життя-пізнання людського), яка, однак, не означає тотожності особистості людини з Богом - інакше це була б не особистість, а чистий інструмент Абсолютної Божої Волі, що було б безжиттєво» [5, с. 163].

Висновки. Таким чином, приходимо до розуміння того, що суб'єктність людини є складним багаторівневим феноменом, функціональний зміст якого визначає онтологічна доцільність існування людини як тіла-душі-духа. Існують три онтологічні рівні суб'єктності: рівень духа - суб'єктна духовна активність постає як реалізація свободи вибору, ціннісне самовизначення і цілепокладання; рівень душі існує як матриця різних форм психічної активності, робота переживання; рівень тіла - як реалізація поведінкових програм в конкретних видах предметної діяльності. Отже, суб'єктність за змістом не тотожна поняттю «психічна активність». Остання є тільки різновидом прояву духовного начала, але не охоплює усієї глибини і повноти змісту суб'єктності. Можна говорити про духовну, психічну, соціальну активності, культуро- і життєтворчість як, зрештою, й про біо-фізіологічне функціонування й тілесну експресію. Феномен суб'єктності проявлятиметься по-різному на різних рівнях функціонування людини: як індивіда, особистості чи індивідуальності. У свою чергу, душевна іпостась визначає онтологічний спосіб актуалізації суб'єктності людини - інтуіиія, а духовна задає онтологічний спосіб ї̈ реалізацї̈-вчинок.

1. Донченко, О. А. (2006). Фрактальність психіки і суб’єктність. В.О. Татенко (Ред.), Людина. Суб'єкт. Вчинок: Філософсько-психологічні студії. (с. 117-143). К.: Либідь.

2. Карпенко, 3. С. (2018). Аксіологічна психологія особистості: монографія. Івано-Франківськ: ДВНЗ «Прикарпатський національний університет імені Василя Стефаника».

3. Карпенко, 3. С. (2006). Картографія інтегральної суб’єктності: пост-постмодерністський проект. В.О. Татенко (Ред.), Людина. Суб’єкт. Вчинок: Філософсько-психологічні студї. (с. 157-175). К.: Либідь.

4. Климишин, О. І. (2013). Християнсько-психологічні основи духовного розвитку особистості. (Дис. док. психол. наук). Національний педагогічний університет ім. М.П. Драгоманова, Київ.

Львів: Логос.

5. Онищенко, В.Д. (1998). Філософія духа і духовного пізнання: Християнсько-філософська ноологія.

6. Киричук О. В., Роменець В. А. (Ред.). (1995). Основи психологіï: Підручник. К.: Либідь.

7. Татенко, В. О. (2000). Суб' єктне ядро в системі психіки. Карпенко 3. С., І. М. Гоян (Ред.). Методологічні і теоретичні проблеми психології: Хрестоматія. (с. 49-54). Івано-Франківськ: Плай.

8. Татенко, В. О. (2006). Суб’єктно-вчинкова парадигма в сучасній психології. Татенко В. О. (Ред.). Людина. Суб'єкт. Вчинок: Філософсько-психологічні студії. (с. 316-358). К.: Либідь.

\section{REFERENCES}

1. Donchenko, O. A. (2006). Fraktalnist psykhiky i subiektnist [Fractality of the psyche and activity]. Tatenko V.O. (Red.). Liudyna. Subiekt. Vchynok: Filosofsko-psykhologichni studii [Man. The subject Action: Philosophical and psychological studies]. (p. 117-143). K.: Lybid. (ukr). 
2. Karpenko, Z. S. (2009). Aksiologichna psyxologiya osobystosti: monografiya [Axiological personality psychology: [monograph]. Ivano-Frankivsk: DVNZ «Prykarpatskyi natsionalnyi universytet imeni Vasylia Stefanyka». (ukr).

3. Karpenko, Z. S. (2006). Kartografiia integral noi sub'iektnosti: post-postmodernistskii proekt [Cartography of Integral activity: post-postmodern project]. Tatenko V.O. (Red.). Liudyna. Subiekt. Vchynok: Filosofs ko-psykhologichni studii [Man. The subject Action: Philosophical and psychological studies]. (p. 157-175). K.: Lybid. (ukr).

4. Klymyshyn, O. I. (2013). Khrystyiansko-psykhologichni osnovy dukhovnogo rozvytku osobystosti. (Dys. dok. psykhol. nauk) [Christian psychological foundations of spirituality of identity. (Dissertation for the degree of Doctor of Psychological Sciences)]. Natsionalnyy pedahohichnyy universytet im. M.P. Drahomanova, Kyiv. (ukr).

5. Onyshchenko, V. D. (1998). Filosofiia dukha i dukhovnogo piznannia: Khrystyians `ko-filosofs `ka noologiia [Philosophy of spirit and spiritual cognition: christian philosophical poetry]. Lviv: Logos. (ukr).

6. Kyrychuk, O. V., Roments V. A. (Ed.). (1995). Osnovy psykhologii: Pidruchnyk [Fundamentals of Psychology: Textbook]. K.: Lybid. (ukr).

7. Tatenko, V. O. (2000). Subiektne iadro v systemi psykhiky [Subjective core in the psyche]. Karpenko, Z. C., Goian, I. M. (Ed.). Metodologichni i teoretychni problemy psykhologii: Xrestomatiia [Methodological and theoretical problems of psychology: Hermes]. (p. 49-54). Ivano-Frankivsk: Plai. (ukr).

8. Tatenko, V. O. (2006). Subiektno-vchynkova paradygma v suchasnii psykhologii [Subjective-task paradigm in modern psychology]. Tatenko V. O. (Red.). Liudyna. Subiekt. Vchynok: Filosofs `ko-psykhologichni studii [Man. The subject Action: Philosophical and psychological studies]. (p. 316-358). K.: Lybid. (ukr).

\section{Olha Klymyshyn \\ PHENOMENOLOGY OF HUMAN AS AN ACTIVE SUBJECT FROM THE POSITION OF CHRISTIAN PSYCHOLOGY}

The article presents the Christian-oriented paradigm of subjectivity of man. The historical act of the psychology will legally lead to the teleologically determined holistic presentation of the person as a physical-soul-spiritual reality and as a carrier and a subject of the spiritual aspirations and abilities. This is also a paradigm of the modern social psychology, Christian-oriented, based on the exposition of the Christian personality on the post-nonclassical type of rationality. Subjectivity is seen as a complex multipsychospiritual phenomenon, the functional content of which determines the feasibility of ontological existence of human as body-mind-spirit. The precious prototype, the "Sample" of its development that teleologically induces it, but also contains the necessary configuration of the instincts that provide the actual ability of the subject to spiritual self-realization (the implementation causal causality) is not only in the transcendental and ontological nature of man. Activity represents divine and human in their synergistic alliance with regard to the initiation, actualization and realization of vital activity at three levels: the spirit - the realization of freedom of choice, value self-determination and goal-setting; the soul - finding personal meaning through experience; the body level - the implementation of behavioral programs in specific types of substantive activities. At the same time, soul hypostasis defines an intuitive way as a priority to actualize activity, and the spiritual determines the way of its implementation through the act. The Divine Spirit determines the creative nature of the human activity of life as Love (from Love, in Love, for Love), giving the person the ontological status of the co-creator. Love as a semantic disposition motivated by the spirit of personality acts is the leading factor in the activity inspired by God.

Keywords: identity, subjectivity, spiritual development, spiritual activity, mental activity, social activity, culture and lifecreation, bio-physiological functioning, bodily expression. 